\title{
PSYCHOLOGICAL DETERMINANTS OF CIVIC ENGAGEMENT
}

\author{
CZYNNIKI MOTYWUJĄCE POWSTAWANIE I UMACNIANIE \\ SPOŁECZEŃSTWA OBYWATELSKIEGO W POLSCE
}

\author{
Danuta Plecka*, Agnieszka Turska-Kawa**
}

\begin{abstract}
An integral part of social discourse is discussions concerning the issue of how to motivate citizens to actively build civil society. Scholars search for the factors that develop and promote pro-civic attitudes. The discussions mostly refer to young citizens, as they are the ones that determine the direction of changes. This article presents a study following the trend of searching for psychological determinants of young people's civic engagement. The researchers found that the determinants include two motivational variables: the sense of self-efficacy, and dispositional optimism. They also diagnosed the structure of values of individuals with different levels of civic engagement.
\end{abstract}

Keywords: civil society, psychological determinants, young people
Integralną częścią dyskursu społecznego są dyskusje podejmujące kwestie mobilizacji obywateli do czynnego budowania społeczeństwa obywatelskiego. Badacze zadają pytania o czynniki kształtujące postawy proobywatelskie oraz o te, które je umacniają. Dyskusje te w szczególności dotyczą młodych obywateli, bowiem to właśnie oni wyznaczają kierunek zmian. Niniejszy artykuł prezentuje badanie wpisujące się w nurt poszukiwań psychologicznych uwarunkowań zaangażowania obywatelskiego młodych ludzi. Wśród tych uwarunkowań zwrócono uwagę na dwie zmienne motywacyjne - poczucie własnej skuteczności oraz dyspozycyjny optymizm, jak również zdiagnozowano strukturę wartości jednostek o różnym poziomie zaangażowania obywatelskiego.

Słowa kluczowe: społeczeństwo obywatelskie, psychologiczne uwarunkowania, młodzi ludzie

\footnotetext{
* University of Zielona Góra, Institute of Political Science.

** University of Silesia in Katowice, Institute of Political Sciences and Journalism.
} 
An integral part of social discourse is discussions concerning the issue of how to motivate citizens to actively build civil society. Scholars search for the factors that develop and promote pro-civic attitudes. The discussions mostly refer to young citizens, as they are the ones that determine the direction of changes. This article presents a study following the trend of searching for psychological determinants of young people's civic engagement. The researchers found that the determinants include two motivational variables: the sense of self-efficacy, and dispositional optimism. They also diagnosed the structure of values of individuals with different levels of civic engagement.

Civil society is a broad category defined in a number of ways, which entails theoretical chaos, mostly resulting from the abundance of ideas (Dzwończyk, 2009). Analyzing the phenomenon, we cannot but agree with Piotr BrodaWysocki that the difficulties in identifying what civil society is do not arise from the lack of proper definition but rather from the excess of definitions (BrodaWysocki, 2003). Thus, civil society can be defined in the context of intermediary structures between the state and the citizens' private sphere (Calhoun, 1999), or with reference to the pluralism of interests occurring in the society, in the pursuit of which citizens voluntarily form organizations (Pérez-Díaz, 1996), or even in the context of community ("the habitat of habitats"), i.e., different levels of citizens' activities with equal rights, without favoring any of them. Notwithstanding the variety of definitions of civil society, we can identify two traditions that are fundamental for its understanding: the liberal one, and the republican one.

They are commonly regarded as contradictory, but clearly they can also complement each other, since they originate from the same canon of values and they compete for being the best model of an engaged society. Civic competencies and the figure of social leader are significant in both the republican and the liberal paradigm. Yet, their intensity differs between the models of civic participation.

One property constituting both the liberal and the republican civic model is the idea of freedom, as without it there would be no citizens or civil society. Obviously, the category has different meanings for the supporters of liberalism and for republicans. The difference is mainly in the significance attributed to the idea: for liberals, freedom equals the lack of force. We may even have the impression that the supporters of liberalism "flee from politics", because in their opinion any engagement in social life or the activity of the community questions the primacy of freedom over other phenomena, and therefore, it poses a threat to freedom. Hence the suspicious attitude towards activities individuals take for the benefit of other citizens. Still, this view of freedom is not common among 
liberals; it is primarily attributed to the supporters of liberalism that Marcin Król calls the liberalism of fear. At the same time, one of its many forms is the view that promote citizens' activity in the public sphere, related to the liberal approach to freedom through its positive dimension (Król, 1996). Its supporters point to the need to "make friends with politics" and "express courage" in influencing it, because the public sphere can only be improved this way, at the same time protecting the freedom of individuals.

It is worth mentioning that such an approach to freedom - stressing its positive dimension - is close to republican concepts. Again, there are two types of republicanism: the "Athenian" and the "Roman" one. The type of republicanism originating from the Roman tradition can be identified with the liberal approach to freedom: it holds that individual freedom has the primacy over community life. As observed by Elżbieta Ciżewska, its supporters avoid the answer to the question of what happiness is, but on the other hand, just like the "Athenian" republicans, they emphasize the role of participation for the common good, and individual's freedom is connected with the freedom of the state (Ciżewska, 2010). Thus, the interpretation of freedom by the supporters of the "Roman" trend is very similar to the assumptions of "liberalism of courage".

The "Athenian" model of republicanism is the most demanding in terms of civic attitudes that make civil society. Its supporters hold the view that a human is a social creature and can only achieve their goals through public activity for the common good. Currently, this view is promoted by communitarians, recognizing that individual good can only be achieved through activity for the common good. Thus, positive freedom and the common good have the primacy over negative freedom and individualism (Karnowska, 2011).

The different notions of freedom in liberal or republican attitudes also give rise to different perceptions of relationships between an individual and a community. Whereas the "liberalism of fear" recognizes the absolute primacy of an individual - understood as an individual entity - over any expressions of community, in the republican concepts and opinions or the "liberalism of courage" the relationships are more complicated. A rational individual with the right to individual happiness and autonomous decisions is not clearly contrasted to the community lifestyle. It is even believed that without individualism the community would lose the ability to participate in pursuing the common good (Weryński, 2008). Naturally, in "Athenian" republicanism individualism is not equalized with community, since its supporters recognize the need of primacy of the community over individualism. 
This way, the problem of different interpretations of civic morality emerges. In this case, the line of division is between citizens' commitment towards one another in republicanism and the value of individual accomplishments in the private sphere in liberalism (Weryński, 2008). This naturally translates into the attitude to the state, because while in the liberal approach civil society is primary to the state and the state is only an instrument to achieve individual interests, for contemporary republicans the state is an emanation of the common good. Therefore, community cannot exist beyond its control. Different liberal and republican attitudes to the state also indirectly influence the concepts of civil society. According to Edmund Wnuk-Lipiński, in communitarian concepts it is civil society that "makes" citizens, and in liberal concepts citizens make civil society, but in order to do so, they must be equipped, first, with appropriate social capital that enables individuals to collaborate, and second, with a minimum measure of civic culture, which enables them to see not only their own particular interest but also the value of the common good (Wnuk-Lipiński, 2005).

Regarding concepts of relationships between the state and the civil society as historical traditions, it must be emphasized that currently it is commonly held that whatever the degree of autonomy, society inevitably assumes the existence of a state (Szacki, 1996). Yet, this does not mean that the relationships between the state and civil society are simple. As Józef Lipiec points out, there are three kinds of relationship on the "state - civil society" axis. First, the mixed model of relationship assumes that the relations between institutions are not constant or inviolable. In this approach, relations are quite dynamic and largely depend on current problems. Hence, they can have the form of strong antagonisms resulting from conflict situations or decisions, but they can also be amicable. Actually, there is no single, constant model of compromise: it is achieved in different ways depending on the situation (Lipiec, 2002).

The other kind of relationships between civil society and the state is a disharmonic model. Its consequence is constant or cyclical occurrence of open conflicts. Usually, they have the form of total opposition, but they may also refer to specific matters. It is worth noting that the disharmony between civil society and the state often leads to weakening both institutions, or at least is not upbuilding and does not foster development. In this model, the state is considered as oppressive by civil society, and civil society is considered as an institution that disturbs and destroys the state (Lipiec, 2002).

Finally, there is the third, optimum model of "harmonious cooperation", following the principle of respecting "separate territories" of activity: the state 
does not invade the sphere of activity of civil society, and the other way round, civil society avoids the planes of traditional activities of the state (Lipiec, 2002). This model is accompanied by the belief that the "two worlds" mentioned above understand the difference between each other, are convinced of the need to collaborate and know about their mutual relations and different principles of activity (Szacki, 1996). The combination of the idea of civil society and democracy is especially important in the context of this model, because in a democratic system we must not separate social issues from political ones (Bokajło, 2001). Therefore, there is a clear specific functional correlation of the phenomena, and it must be stressed that at the moment negative relationships between the state and civil society are not standard.

The type of democracy and the degree of development of civil society are another thing ${ }^{1}$. When discussing the problem of deficit or degeneration of democracy, the directions of improvement are often pointed out. On the one hand, the return to sources of democracy is demanded, and on the other hand, "democratic revisionism". According to Wiesław Bokajło, in both cases it is necessary to work out the form of democracy which: 1) is effective both in terms of exercising power and reaching a compromise and maintaining social balance, and 2) has clearly, precisely and coherently formulated competencies, i.e., rights and obligations of political institutions, authorities and citizens (Bokajło, 2001). Disregarding the institutional problems of democracy, unimportant for this analysis, we need to try and determine the role of civil society for the degree of consolidation of democracy or overcoming crises. What is interesting in this perspective is proposals of "democratic revisionism", i.e., not the return to the sources of democracy but rather the revision and rationalistic adaptation to the dynamics of the contemporary world (Wnuk-Lipiński, 2005).

"Democratic revisionists" present two different attitudes to the problem, referred to in literature as "elitist" and "participatory" ones. While referring to human rationality and the need of maximizing their interest by the actions taken, "elitists" also emphasize that individual rationalism does not have to add up at the social level (Sartori, 1994). This is mostly connected with the more and

1 Generally, theories of democracy include: normative ones (answering the question of what should be) and empirical ones (answering the question of what really is). However, the research problem of this article does not allow us to elaborate on the theories of democracy. Andrzej Antoszewski (2016) described theories of democracy very thoroughly in the book Współczesne teorie demokracji, Warszawa. 
more complicated reality and the lack of broad civic, political and economic competencies among citizens. Hence the demand that democracy should develop thanks to the activity of so-called political class and the emerging elite of power ensuring formal legitimization of the elite on the part of electorate activating only at elections (Bokajło, 2001). This discussion does not involve the "elitist" concept, but in the context of this analysis it must be stressed that its supporters regard the state to be the carrier of power, and non-state organizations and citizens are only social participants.

The trend of "democratic revisionism", in turn, involves the approach in which the primary principle is citizens' equality both in terms of law and in terms of communities and political participation. The "participatory" approach assumes that decisions concerning the public domain must be taken by as broad circles of stakeholders as possible, because the effects of the decisions will affect the whole community. It may be said that this approach is coincident with the concept of polyarchy by Robert Dahl (1971), who pointed out that democracy is characterized by government's constant positive response to citizens' preferences, whereas citizens have equal political rights. In the area of citizen's engagement defined this way it is obviously necessary to expect some political competencies of them (Plecka, Turska-Kawa, Wojtasik, 2013).

Knowledge on politics, the culture of social trust, the need to act and an axiological system are all important for the development of the attitude of an aware and engaged citizen. There is a kind of paradox, however, because the level of political civic competence is influenced by the formation and strengthening of values, especially in the political dimension. This means that the elements of competence such as knowledge on politics or the culture of social trust and political participation are not only the entities that constitute the phenomenon, but also the "civic values". They affect the quality of civic political competence and the quality of civil society, and - even more important - the degree of consolidation of democracy.

However, two significant problems appear. Firstly, the more and more complicated reality is not very comprehensible for a great number of citizens. Thus, psychological determinants (frustration, dissatisfaction, pessimism) consolidate, limiting the possibility of participating in public and social life. This specific "closing" leads to political, electoral and participatory alienation. We no longer represent attitudes connected with republicanism or liberalism of "courage", and the reference to liberalism of "fear" is more and more often dominant. It is based on dispositional pessimism, especially with regard to political and social reality. 
It strengthens the belief in the low level of self-efficacy, thus discouraging the formation of social capital and improvement of civil society.

The opposite effect can be achieved when dispositional optimism (the way of perceiving the world that in which we expect more positive than negative experiences) or the sense of self-efficacy (individual level of general belief in being able to cope with difficult situations and obstacles) are dominant in the society (Juczyński, 2001). Optimism is largely responsible for motivating to action, endurance in performing projects, and engagement, so it seems understandable that optimists have a higher sense of self-efficacy. Believing in self-efficacy provides the basis for motivation, effects of activity, and personal skills. Self-efficacy influences the choices we make and the related efforts, and determines how long we continue making the effort when we meet obstacles and how we feel about this situation (Bańka, 2005). Besides, people with a higher level of this variable often display a low level of anxiety understood as a personal trait.

Both the sense of self-efficacy and dispositional optimism are dispositional traits which are largely responsible for motivating individuals to act. Optimists employ more effective strategies of coping in difficult situations, such as problemoriented coping rather than denial, diverting attention, or discontinuing the activity. In stressful situations pessimists tend to concentrate on emotions instead of the problem. For them a failure is not an impulse to give up but to maintain the effort (Scheier, Carver, Bridges, 1994). The sense of self-efficacy implicates higher engagement in activities, because the low level of our motivations, affective states and actions we take are more based on what we believe in and on whether we feel able to do something than on the objective reality (Bańka, 2005). Studies prove that its high level correlates with helplessness, depression, and high susceptibility to stress (Bańka, 2005; Juczyńki, 2001). It is found that people who do not believe in their ability to cope with difficult tasks adopt this as a way of life. They dwell upon their personal deficits and failures, complain about their lot in life, and easily give up. Since they have little faith in their own abilities, a little dose of failure is enough to make them lose the faith completely (Bańka, 2005).

Many empirical studies prove the existence of significant relations between the values preferred by a person and the person's behaviors (e.g., Bardi, Schwartz, 2003; Schwartz, 2006; Turska-Kawa, 2016). Most theories assume that values serve the motivational function and involve a great emotional load. Stanisław Jałowiecki (1979), a representative of the sociological approach, identifies a value as any material or ideal item, an idea, an institution, a real or imagined thing towards which individuals or communities have the attitude of respect, con- 
sider it to have an important role in their lives and feel the imperative desire to achieve it. In the approach by Milton Rokeach (1973), values are beliefs with an emotional aspect, affecting the choice of goals and ways of achieving them. The approach of Shalom Schwartz (1992) treats values as ideas or beliefs which refer not only to specific situations, but to ultimate final states or behaviors. Values determine the choice or evaluation of behaviors and events and are organized in accordance with their relative importance. Economist Nikolai Nenovsky (1987) points out that values always have the meaning that is attributed to them by people. They reflect the individual's attitude to the external world, and are related to the needs, interests, feelings, and desires.

One theory that makes it possible to analyze the relations between the fundamental values and civic activity is the Theory of Basic Human Values by Shalom Schwartz. According to Schwartz (1992; Schwartz et al., 2012), values are associated with emotions. The author underscores that they are connected with the goals the person prefers and are the motivation to act. Schwartz's concept identifies ten types of basic values: conformity, tradition, benevolence, universalism, self-direction, stimulation, hedonism, achievement, power, and security. The core of the theory is two properties of the structure of values: the continuum and circular character. Values make a continuum, which means that each fragmentation of the continuum into separate units is arbitrary. But it is possible to divide the continuum of values in different ways into more detailed or more general units (Cieciuch, 2013). The continuum of values as perceived by Schwartz (1992) is motivational in character, i.e., values located close to each other are motivationally similar and may be pursued together. The continuum of values is circular, which adds an important element to the properties of the structure: values located on the opposite sides of the circle exclude each other. The circular structure of the ten values can also be described using two dimensions: self-enhancement versus self-transcendence and openness to change versus conservation.

\section{RESEARCH PROBLEM AND METHODOLOGY}

The goal of the presented empirical study is to analyze psychological determinants of civic attitude. In the light of the information above, this attitude is understood as a citizen's activity and ability to self-organize, collaborate with others, and achieve the set goals without external impulse or pressure. 
The study seeks the determinants of civic engagement in psychological variables such as dispositional optimism and the sense of self-efficacy. These variables are responsible for activation and better strategies of coping with difficult situations, which will presumably translate into stronger civic attitude. The aim of the study is also to diagnose the structure of basic values of individuals with different levels of civic engagement.

The study was carried out among 548 students from the University of Silesia in Katowice and Nicolaus Copernicus University in Torun. The participants were 320 women and 228 men. They were all students of courses such as: Politology, Political and Public Consultancy, Journalism and Social Communication, History, Philosophy and Internal Security.

The respondents individually completed the questionnaire. The instrument diagnosed the variables analyzed in the study: the level of civic engagement and basic values, dispositional optimism and the sense of self-efficacy.

The theoretical basis for the constructed tool for studying civic engagement is the definition of civic engagement formulated in the official document of The Centre for Civil Society of London School of Economics, which describes it as the area of voluntary collaboration for common interests, goals and values. Further, the document points out that civil society is the plane of activity of different organizations, such as formal charities, pro-developmental non-governmental organizations, communities, women's organizations, religious associations, trade unions, self-help groups, social movements, associations of entrepreneurs, coalitions and interest groups. The soft tissue of civil society is social capital, involving groups of broadly understood competencies, attitudes and beliefs, i.e., the civic approach of members of society, social norms supporting common activities and interpersonal trust, as well as citizens' trust in public institutions (Putnam, 1993), and informal values or ethical norms shared by members of a certain group, allowing them to effectively collaborate on the basis of mutual trust (Fukuyama, 1997) and individual contribution into networks of social relationships (Bourdieu, 1986, 1993).

Therefore, civil society is an active, open, democratic, solidary, free and responsible society, organized at the grass-roots level through various horizontal structures (Gliński, 2009). A member of such a community has specific qualities: the optimum level of trust in other people, readiness to collaborate to achieve common interests, taking the initiative, responding to calls to action, and sharing norms and values with the social group. Civic engagement understood this way was operationalized using a scale made up of 6 statements, 
which the respondents evaluated on a five-point scale. The scale included the following items:

1. In the community you should only care about your own interest.

2. Common good is important for me.

3. Other people have good intentions.

4. I like to engage in different formalized social groups (associations, unions, etc.).

5. I am interested in what happens around my place of residence.

6. I like to take part in organizing different activities for the people living in my area (festivities, social initiatives, celebrations, etc.).

The reliability of this scale $\alpha=0.79$.

The sense of self-efficacy was diagnosed with the General Self-Efficacy Scale (GSES) by Ralf Schwarzer, Michael Jerusalem and Zygfryd Juczyński. The authors draw on the concept of expectations and the idea of self-efficacy by Albert Bandura. Expectation of self-efficacy is connected with the control of one's actions and may either refer to specific areas of the individual's life or be a general belief concerning new or difficult situations.

Dispositional optimism was diagnosed using the Life Orientation Test (LOT) by Michael F. Scheier, Charles S. Carver and Michael W. Bridges, adapted into Polish by Ryszard Poprawa and Zygfryd Juczyński.

The structure of values was diagnosed using the S-PVQ (Short Portrait Values Questionnaire; Beierlein et al., 2014). It is a shortened version of classic PVQ (Portrait Values Questionnaire) by Schwartz, presented at the $28^{\text {th }}$ International Congress of Applied Psychology in Paris. The tool is composed of 13 short descriptions of persons (e.g., "It is important to him to be rich", "It is important to him to make his own decisions about what he does", "He believes that people should do what they are told"). The respondent decides to what degree the description matches their personality. Respondents can use a 6-point scale (from "not at all like me" to "exactly like me"). The scale diagnoses four higher-order values: self-transcendence, self-enhancement, conservation, openness.

Since people much more often consider themselves as similar to descriptions, the results were subject to ipsatization. The procedure involves deducting the mean of all the items for the person from the mean for the index obtained by the person in each of the identified values. The positive scores obtained this way mean the location of the value above the mean in the system of values of a person or group. Negative values point to a preference below the mean. Zero values reflect a medium place in the system of values. 


\section{EMPIRICAL FINDINGS}

To verify the goals of the study, at the first stage of the analysis the raw scores obtained by the respondents on the civic engagement scale were replaced by a standard ten scale in order to identify three comparative groups: the group with a low (standard tens 1-3), medium (4-7) and high (8-10) level of civic engagement. The first group was made up of 172 persons (101 women, $71 \mathrm{men}$ ), the second, 269 persons ( 187 women, $82 \mathrm{men}$ ), and the third one, 107 persons (32 women, 75 men). The mean standard ten value for the first group was 2.3; for the second one, 5.1, and for the third one, 8.6.

Further, the mean levels of dispositional optimism were verified (for the whole group: 21.4) and self-efficacy (for the whole group: 29.1) in the three identified groups with different levels of civic engagement (Table 1).

Table 1. Results of analysis of variance and post-hoc Tukey HSD Test for dispositional optimism and the sense of self-efficacy in groups with different levels of civic engagement

\begin{tabular}{|c|c|c|c|c|c|c|c|c|c|}
\hline \multirow[t]{2}{*}{ Variable } & \multicolumn{2}{|c|}{$\begin{array}{l}\text { Low level of } \\
\text { civic engage- } \\
\text { ment (LLCE) }\end{array}$} & \multicolumn{2}{|c|}{$\begin{array}{l}\text { Medium level of } \\
\text { civic engage- } \\
\text { ment (MLCE) }\end{array}$} & \multicolumn{2}{|c|}{$\begin{array}{l}\text { High level of } \\
\text { civic engagement } \\
\text { (HLCE) }\end{array}$} & \multicolumn{2}{|c|}{ ANOVA } & \multirow[t]{2}{*}{ Tukey's HSD } \\
\hline & Value & $\begin{array}{l}\text { Standard } \\
\text { deviation }\end{array}$ & Value & $\begin{array}{l}\text { Standard } \\
\text { deviation }\end{array}$ & Value & $\begin{array}{l}\text { Standard } \\
\text { deviation }\end{array}$ & F & p & \\
\hline $\begin{array}{l}\text { Dispo- } \\
\text { sitional } \\
\text { optimism }\end{array}$ & 19.4 & 3.49 & 20.1 & 3.87 & 22.3 & 3.11 & 4.323 & 0.01 & $\begin{array}{c}\text { LLCE/HLCE } \\
\mathrm{p}=0.00 \\
\text { MLCE/HLCE } \\
\mathrm{P}=0.02\end{array}$ \\
\hline $\begin{array}{l}\text { Self-effi- } \\
\text { cacy }\end{array}$ & 27.5 & 4.70 & 27.9 & 4.23 & 30.2 & 4.99 & 5.468 & 0.01 & $\begin{array}{c}\text { LLCE/HLCE } \\
\mathrm{p}=0.00 \\
\text { MLCE } / \text { HLCE } \\
\mathrm{P}=0.00\end{array}$ \\
\hline
\end{tabular}

Source: Author's.

The results of the analysis of variance showed that individuals with a high level of civic engagement represent significantly higher levels of dispositional optimism and sense of self-efficacy than do individuals with a low or medium level of civic engagement. There were no significant differences in the scores obtained by groups with the low and medium level of civic engagement in terms of the analyzed variables. 
The diagnosis of values carried out with the use of S-PVQ had satisfactory reliability indices. Cronbach's alpha for each scale was between 0.59 (for openness) and 0.71 (for self-transcendence), as shown in Table 2.

Table 2. Cronbach's alpha for the higher-order values investigated in the study

\begin{tabular}{|l|c|}
\hline \multicolumn{1}{|c|}{ Value } & Cronbach's alpha \\
\hline Self-transcendence & 0.71 \\
\hline Self-enhancement & 0.69 \\
\hline Conservation & 0.61 \\
\hline Openness & 0.59 \\
\hline
\end{tabular}

Source: Author's.

Then, the structure of basic values was verified for the groups representing different levels of civic engagement, as shown in Table 3.

Table 3. Results of analysis of variance and post-hoc Tukey HSD Test for the analyzed basic values in groups with different levels of civic engagement

\begin{tabular}{|l|c|c|c|c|c|c|}
\hline \multirow{2}{*}{ Value } & \multicolumn{5}{|c|}{ Mean } & \multicolumn{2}{c|}{ ANOVA } & Tukey's HSD \\
\cline { 2 - 7 } & $\begin{array}{c}\text { Low level } \\
\text { of civic en- } \\
\text { gagement } \\
\text { (LLCE) }\end{array}$ & $\begin{array}{c}\text { Medium } \\
\text { level of civic } \\
\text { engagement } \\
\text { (MLCE) }\end{array}$ & $\begin{array}{c}\text { High } \\
\text { level of civic } \\
\text { engagement } \\
\text { (HLCE) }\end{array}$ & $\mathbf{F}$ & $\mathbf{p}$ & \\
\hline $\begin{array}{l}\text { Self-transcen- } \\
\text { dence }\end{array}$ & 0.27 & 0.35 & 0.51 & 3.542 & 0.002 & $\begin{array}{c}\text { LLCE/HLCE } \mathrm{p}=0.001 \\
\text { MLCE/HLCE } \mathrm{p}=0.02\end{array}$ \\
\hline $\begin{array}{l}\text { Self-enhance- } \\
\text { ment }\end{array}$ & -0.91 & -1.11 & -1.43 & 3.854 & 0.006 & $\begin{array}{c}\text { LLCE/HLCE } \mathrm{p}=0.000 \\
\text { MLCE/HLCE } \mathrm{p}=0.011\end{array}$ \\
\hline Conservation & 0.59 & 0.34 & 0.18 & 12.122 & 0.000 & $\begin{array}{c}\text { LLCE/HLCE } \mathrm{p}=0.001 \\
\text { LLCE/MLCE } \\
\text { P=0.019 }\end{array}$ \\
\hline Openness & 0.26 & 0.30 & 0.42 & 8.946 & 0.000 & $\begin{array}{c}\text { LLCE/HLCE } \mathrm{p}=0.023 \\
\text { MLCE/HLCE } \mathrm{p}=0.034\end{array}$ \\
\hline
\end{tabular}

Source: Author's.

The higher order value "self-transcendence" was evaluated higher in all the analyzed groups than was "self-enhancement". Such tendencies emerge from many other empirical studies (e.g., Zarzycka, Dawidowicz, Koziatek, 2007; 
Cieciuch, 2010; Pilch, 2012; Turska-Kawa, 2016; Ramos, 2006). The post hoc test showed that self-transcendence is assessed significantly higher by people with a high level of civic engagement than by those with the lowest of medium level. The same applies to the meta value of self-enhancement. In the case of value "self-enhancement", the opposite is true: individuals with a higher level of civic engagement evaluate it lower than do people with low or medium engagement. As regards these two meta values, the groups with the medium and low level of civic engagement are homogeneous.

The growth of civic engagement is reversely proportional to the preference for conservation. The post hoc test showed significant differences in all the analyzed groups. It is similar in the case of openness: civic engagement is promoted by preference for openness, which is also clearly shown by the post hoc test, but in this case groups with the low or medium engagement do not display any differences. When dividing the results by groups, we can see that openness is only evaluated higher than conservation in the group with a high level of civic engagement. The other two groups display higher preference for conservation.

\section{CONCLUSIONS}

The presented research tackled the problem of psychological determinants of civic engagement. The determinants were sought in basic values preferred by individuals and in the motivational variables: dispositional optimism and the sense of self-efficacy. The results of the study showed that these variables are significant for civic engagement. Motivational variables occur significantly more in individuals with a high level of civic engagement than in those with low or medium engagement. The more active people display higher levels of dispositional optimism and sense of self-efficacy. With regard to values it was proved that civic engagement is fostered by the preference for self-transcendence and openness. Those for whom conservation and self-enhancement are more important are more often passive.

The results of the study allow an optimistic view on the formation and strengthening of civil society in Poland by young people. First if all, both from the perspective of "liberalism of courage" and "liberalism of fear", i.e., dispositional optimistic attitude that promotes openness and citizen's participation in the development of political, personal and social reality. In this context, it is also worth stressing that in the models which are the starting point for the present 
discussion citizenship is both a legal status and a social role. Our respondents demonstrated that they have preferences for civic engagement, which does not have to mean that it is the most important thing in their lives.

As we know, people who represent civic attitudes have a twofold influence on the state: direct and indirect. The aim of the above analyses was to study the direct influence through potential psychological determinants of activity as part of the concept of civil society. According to Jacek Raciborski, two types of civil society can be identified: one is constituted by citizens that communicate and associate in order to induce the state to allocate some goods in a way beneficial for them (which refers to the tradition of "liberalism of courage") and the other is an autonomous civil society as a sphere of private interests that are naturally egoistic and conflicting. In this sphere, individuals associate and cooperate voluntarily to effectively satisfy their needs (Raciborski, 2010). The results of the analyses lead to the conclusion that the young participants' preferred attitudes of openness and belief in their abilities may relate to both interpretations of civil society. Besides, it is hard to decide which liberal tradition is dominant, because the types may be considered as facets of civil society. Sometimes one facet is more visible, and sometimes the other. These facets or types are like the obverse and reverse of a coin (Raciborski, 2010). However, the direction of changes among young people and the perspectives of strengthening civil society are the most important both for the quality of social life and for democracy.

\section{REFERENCES:}

Bańka, A. (2005). Poczucie samoskuteczności. Konstrukcja i struktura czynnikowa Skali Poczucia Samoskuteczności w Karierze Międzynarodowej. Poznań, Warszawa: Studio PRINT-B, Instytut Rozwoju Karier.

Bardi, A., Schwartz, S.H. (2003). Values and Behavior: Strength and Structure of Relations. Personality and Social Psychology Bulletin, 29(10), 1207-1220. DOI: 10.1177/0146167203254602.

Beierlein, C., Davidov, E., Cieciuch, J., Rammstedt, B., Schwartz, S.H. (2014). The Schwartz Values Short Scale. An Economic Measurement Tool for Cross-Cultural Research. Paper presented at the 28 ${ }^{\text {th }}$ International Congress of Applied Psychology, Paris, France.

Bokajło, W. (2001). Społeczeństwo obywatelskie: sfera publiczna jako problem teorii demokracji. In: W. Bokajło, K. Dziubka (eds.), Społeczeństwo obywatelskie. Wrocław: Wydawnictwo Uniwersytetu Wrocławskiego.

Bourdieu, P. (1986). The Forms of Capital. In: J.G. Richardson (ed.), Handbook of Theory and Research for the Sociology of Education. Westport, C.T.: Greenwood Press. 
Bourdieu, P. (1993). The Field of Cultural Production. Columbia: Columbia University Press.

Broda-Wysocki, P. (2003). Rozwój społeczeństwa obywatelskiego w Polsce: analiza na przykładzie regionów koszalińskiego i opolskiego. Warszawa: IPiSS.

Calhoun, C. (1999). Nacjonalizm i społeczeństwo obywatelskie: demokracja, zróżnicowanie i samookreślenie (transl. J. Szacki). In: J. Szacki (ed.), Ani książę, ani kupiec: obywatel. Idea społeczeństwa obywatelskiego w myśli współczesnej. Kraków: Znak; Warszawa: Fundacja im. Stefana Batorego.

Cieciuch, J. (2010). Nadzieja jako moderator związku poczucia koherencji z preferencjami wartości. Kwartalnik Naukowy Fides et Ratio, 2(2), 25-38.

Cieciuch, J. (2013). Pomiar wartości w zmodyfikowanym modelu wartości Shaloma Schwartza. Psychologia Społeczna, 8(1), 22-41.

Ciżewska, E. (2010). Filozofia publiczna Solidarności. Solidarność 1980-981 z perspektywy republikańskiej tradycji politycznej. Warszawa: Narodowe Centrum Kultury.

Dahl, R. (1971). Demokracja i jej krytycy. Kraków: Wydawnictwo „Znak”.

Dzwończyk, J. (2009). Polityczne aspekty rozwoju społeczeństwa obywatelskiego w Polsce po 1989 roku. Kraków: Wydawnictwo Uniwersytetu Ekonomicznego.

Fukuyama, F. (1997). Zaufanie. Kapitał społeczny a droga do dobrobytu. Warszawa: Wydawnictwo Naukowe PWN.

Fukuyama, F. (2000). Kapitał społeczny. In: L.E. Harrison, S.P. Huntington (eds.), Kultura ma znaczenie. Poznań: Zysk i S-ka.

Gliński, P. (2009). Społeczeństwo obywatelskie w Polsce - dwadzieścia lat przemian. In: R. Glajcar, W. Wojtasik (eds.), Transformacja systemowa w Polsce 1989-2009. Próba bilansu. Katowice: REMAR.

Jałowiecki, S. (1979). Struktura systemu wartości. Stadium zróżnicowań międzygenetycznych. Warszawa: PWN.

Juczyński, Z. (2001). Narzędzia pomiaru w promocji i psychologii zdrowia. Warszawa: Pracownia Testów Psychologicznych.

Karnowska, D. (2011). Spór o wspólnoty. Idee komunitarystyczne we współczesnej polskiej myśli politycznej. Toruń: Wydawnictwo Adam Marszałek.

Król, M. (1996). Liberalizm strachu czy liberalizm odwagi. Kraków: Znak; Warszawa: Fundacja im. Stefana Batorego.

Lipiec, J. (2002). Społeczeństwo obywatelskie - analiza esencjalna. In: B. GoryńskaBittner, J. Stępień (eds.), Społeczeństwo obywatelskie w procesie integracji europejskiej. Poznań: Wydawnictwo Akademii Rolniczej im. A. Cieszkowskiego.

Nenovsky, N. (1987). Law and Values. Moscow: Progress.

Pérez-Díaz, V. (1996). Powrót społeczeństwa obywatelskiego w Hiszpanii. Kraków: Znak; Warszawa: Fundacja im. Stefana Batorego.

Pilch, I. (2012). Wartości podstawowe a preferencje ideologiczne i decyzje wyborcze w wyborach do Sejmu 2011. Preferencje Polityczne, 3, 127-144.

Plecka, D., Turska-Kawa, A., Wojtasik, W. (2013). Obywatelskie kompetencje polityczne. Kultura i Edukacja, 3, 73-98. 
Putnam, R.D. (1993). Making Democracy Work: Civic Traditions in Modern Italy. Prince-Ton:

Princeton University Press.

Raciborski, J. (2010). Wprowadzenie: oblicza obywatelstwa. In: J. Raciborski (ed.), Praktyki obywatelskie Polaków. Warszawa: IPiSS.

Ramos, A. (2006). Social Values Dynamics and Socio-Economic Development. Portuguese Journal of Social Science, 5(1), 35-64.

Rokeach, M. (1973). The Natures of Human Values. New York: The Free Press.

Sartori, G. (1994). Teoria demokracji. Warszawa: PWN.

Scheier, M.F., Carver C.S., Bridges, M.W. (1994). Distinguishing Optimism from Neuroticism (and Trait Anxiety, Self-Mastery, and Self-Esteem): A Reevaluation of the Life Orientation Test. Journal of Personality and Social Psychology, 67, 1063-1078.

Schwartz, S.H. (2006). Basic Human Values: Theory, Measurement and Applications. Revue française de sociologie, 47(4), 249-288.

Schwartz, S.H. (1992). Universals in the Content and Structure of Values: Theoretical Advances and Empirical Tests in 20 Countries. Advances in Experimental Social Psychology, 25, 1-65.

Schwartz, S.H., Cieciuch, J., Vecchione, M., Davidov, E., Fischer, R., Beierlein, C., Ramos, A., Verkasalo, M., Lonnqvist, J.E., Demirutku, K., Dirilen-Gumus, O., Konty, M. (2012). Refining the Theory of Basic Individual Values. Journal of Personality and Social Psychology, 103(4), 663-688.

Szacki, J. (1996). Wstęp. In: J. Szacki (ed.), Ani książę, ani kupiec: obywatel. Idea społeczeństwa obywatelskiego w myśli wspótczesnej. Kraków: Znak; Warszawa: Fundacja im. Stefana Batorego.

Turska-Kawa, A. (2016). Preferowane wartości podstawowe a zachowania wyborcze w elekcji parlamentarnej 2015 roku. Preferencje Polityczne, 12, 105-119.

Weryński, P. (2008). Wzory uczestnictwa obywatelskiego Polaków. Warszawa: IPiSS.

Wnuk-Lipiński, E. (2005). Socjologia życia publicznego. Warszawa: „Scholar”.

Zarzycka, B., Dawidowicz, M., Koziatek, E. (2007). Typy samoświadomości a preferencja wartości. In: P. Francuz, W. Otrębski (eds.), Studia z psychologii w KUL, tom 14. Lublin: Wydawnictwo KUL. 